\title{
Analiza językowa testów psychologicznych - różnorodność interpretacji pozycji testowych a wiarygodność narzędzia
}

\author{
Katarzyna Liber-Kwiecińska \\ Uniwersytet Jagielloński w Krakowie \\ katarzyna.liber@uj.edu.pl
}

\section{Agnieszka Skorupa}

Uniwersytet Śląski w Katowicach

agnieszka.skrupa@us.edu.pl

\section{Streszczenie}

Testy psychologiczne to narzędzia stużace do pomiaru natężenia danej cechy psychicznej u osoby badanej. Pomiar ten $w$ wielu przypadkach odbywa się za pośrednictwem pytań lub stwierdzeń, do których ustosunkowuja się badani. Choć narzędzia psychologiczne podlegaja wysokiej standaryzacji i przykłada się duża wage do ich parametryzacji, sfery językowa testów zdaje się być uznawana za drugoplanową. Sposób sfomułowania pytań testowych, $w$ zależności od tego, czy oparte będa na hiponimach lub hiperonimach, może w znacznym stopniu wptynać na udzielona przez badanego odpowiedź, a przez to obniżyć trafność teoretyczna narzędzia. Autorki artkutu przeprowadzity badanie, w którym 637 osób wypetniało test psychologiczny FCZ-KT (Strelau, Zawadzki 1995), a następnie opisywało sytuacje, które przywołali w pamięci ustosunkowując się do 20 ze 120 pytań z tegoż testu (pytania zostały wyłonione wcześniej podczas badania pilotażowego). Odpowiedzi otwarte udzielone przez badanych zostały skategoryzowane przez sędziów kompetentnych. W niniejszym artykule przedstawione zostanie spektrum różnorodnych skojarzeń jakie u osób badanych budzi ten sam item. Refleksji poddana zostanie sfera językowa testów psychologicznych jako wpływająca $w$ sposób istotny na wiarygodność narzędzia.

Stowa kluczowe: testy psychologiczne, schematyzacja, konkretyzacja, interpretacja testu psychologicznego

\section{Abstract}

Linguistic Analysis of Psychological Inventory

- a Variety of Interpretations of Inventory Points and the Issue of Inventory Credibility

Psychological inventories are tools used to measure intensity of a given trait in an examined person. Many inventories are based on written questions to which people respond. Although 
psychological inventories are standardized and their parameterization is a matter of great importance, the linguistic sphere of tests seems to be considered as secondary. The way in which the inventory questions are structured, depending on whether they are based on hyponyms or hyperonyms, has a significant impact on the response given by people diagnosed. Moreover, it can reduce theoretical validity of the tool. The authors of the article conducted a study in which 637 people completed the FCZ-KT inventory (Strelau, Zawadzki 1995). Next, the respondents described situations in which they recalled answering 20 out of 120 questions from the inventory (questions were selected earlier during the pilot study). Open answers given by the respondents were categorized by competent judges. This article presents the spectrum of various associations that the same item evokes in different respondents. The linguistic aspect of psychological tests and the issue of credibility of tools related to it is the main subject of the article.

Key words: psychological inventory, schematic presentation, specific structuring, inventory interpretation

\section{Wstęp}

Test psychologiczny, najogólniej rzecz ujmując, to narzędzie służące do pomiaru natężenia danej cechy psychicznej u osoby badanej. Testy psychologiczne wykorzystywane są do diagnozy cech jednostki, przewidywania szeroko rozumianego sukcesu badanego czy w celu weryfikacji teorii psychologicznych (Mańkowska 2010: 10-11). I choć istnieje szereg wskaźników tzw. dobroci testu', a sposoby jego konstruowania i stosowania są ściśle skodyfikowane, testy psychologiczne zdecydowanie nie są narzędziami idealnymi. Częściowym remedium na problemy związane ze sferą testowania jest wysoka standaryzacja, której podlegają narzędzia psychologiczne, czyli tworzenie ujednoliconych warunków badania (por. American Educational Research Association i in. 2007: 23-28), dlatego szeroko dyskutuje się o kompetencjach, jakimi powinien odznaczać się potencjalny twórca i użytkownik testu, omawia się kwestie świadomości metodologicznej i odpowiedzialności etycznej badacza, a przede wszystkim kodyfikuje się etapy konstrukcji narzędzi (por. Brzeziński 2003: 455-458). Zdaniem autorek kwestią stosunkowo rzadko rozważaną, a nie mniej istotną dla standaryzacji testów psychologicznych, jest ich sfera językowa.

Narzędzia psychologiczne bazujące na materiale werbalnym² ${ }^{2}$, czyli testy składające się ze zdań, twierdzeń lub pytań (tzw. itemów lub pozycji testowych), do których badany musi się ustosunkować w trakcie wypełniania kwestionariusza, są powszechnie stosowane w praktyce

\footnotetext{
${ }^{1}$ Dobroć testu to kryteria formalne, jakie winien spełniać każdy test, które obejmują jego obiektywność, standaryzację, rzetelność, trafność, normalizację i właściwą adaptację, zob. Hornowska (2007).

${ }^{2}$ Istnieją także testy psychologiczne bazujące na materiale niewerbalnym (liczby, symbole), mierzące poziom wykonania danego zadania czy czas reakcji na bodziec.
} 
psychologicznej. Oznacza to, że jakość testu psychologicznego będzie zależeć w dużej mierze od tego, jak zostaną sformułowane poszczególne jego pytania. Istotnie w różnorodnych opracowaniach z psychometrii ${ }^{3}$ porusza się kwestię analizy pozycji testowych, której celem jest ustalenie ich obiektywnych cech (Guilford 2005: 111). W Standardach dla testów stosowanych w psychologii i pedagogice (American Educational Research Association i in. 2007: 76-95) podkreśla się duże znaczenie etapu tworzenia i weryfikacji pozycji testowych tak, aby pomiar cech z ich użyciem był jak najbardziej rzetelny. Zaleca się wręcz prowadzenie badań mających na celu ,identyfikowanie aspektów treści, formatu pozycji lub kryteriów oceny, które nie mają związku z mierzonym konstruktem” (American Educational Research Association i in. 2007: 81). O ile teoretycznie kwestia sposobu sformułowania treści testu i ewentualnych rozbieżności w interpretacji jego poszczególnych pytań jest uwzględniana przez psychologów, o tyle w praktyce - zdaniem autorek - autorzy testów nie poświęcają dostatecznej uwagi analizie sfery językowej.

Celem niniejszego opracowania było przedstawienie, jak ważne jest precyzyjne formułowanie pozycji testowych tak, aby zmaksymalizować ich trafność teoretyczną i zminimalizować różnice w konkretyzacjach pojawiających się u różnych osób. Swoją analizę językową autorki przeprowadziły na podstawie testu FCZ-KT (Formalna Charakterystyka Zachowania - Kwestionariusz Temperamentu; Zawadzki, Strelau 1995). Analizie takiej mogłoby zostać poddane dowolne narzędzie psychologiczne, nie ma bowiem przesłanek, które wskazywałyby, że powinien jej podlegać szczególnie kwestionariusz FCZ-KT. Co istotne wnioski, które można wyciągnąć na podstawie przeprowadzonego badania, są uniwersalne i mogą podlegać generalizacji - odnosić się do większości narzędzi psychologicznych bazujących na materiale werbalnym.

W dobie badań interdyscyplinarnych, gdy mamy świadomość, że ograniczanie badań wyłącznie do metod typowych dla jednej tylko dyscypliny mocno zawęża perspektywę naukową, wydaje się, że połączenie w procesie tworzenia testów psychologicznych dwóch różnych kompetencji: psychologicznej i lingwistycznej, może przyczynić się do zwiększenia ich trafności teoretycznej, a tym samym umożliwi konstruowanie lepszych narzędzi diagnostycznych i badawczych. Zaprezentowane w niniejszym artykule badanie jest owocem właśnie podejścia interdyscyplinarnego, łączącego psychologię z językoznawstwem, które ma

${ }^{3}$ Jest to dział psychologii, w ramach którego badacze zajmują się teorią i praktyką stosowania testów psychologicznych. 
unaocznić, jak z perspektywy analizy lingwistycznej wygląda w praktyce narzędzie psychologiczne.

$\mathrm{W}$ niniejszym artykule zaprezentowano analizę językową przeprowadzoną $\mathrm{w}$ ramach opisanego badania. Pozostała część badania, w której kategorie konkretyzacji w poszczególnych pozycjach testowych zostały poddane analizie ilościowej z wykorzystaniem programu NVivo i narzędzia SPSS, zostanie zaprezentowana w czasopiśmie psychologicznym.

\section{Problem uszczególowienia pozycji testowych na przykładzie FCZ-KT}

Test FCZ-KT to kwestionariusz służący do pomiaru temperamentu dorosłego człowieka, stworzony na podstawie Regulacyjnej Teorii Temperamentu (RTT) autorstwa Jana Strelaua (por. np. Zawadzki, Strelau 1997: 11-40), w myśl której temperament każdego człowieka można ująć w kategoriach energetycznych (intensywność i zakres podejmowanych działań) i czasowych (szybkość i tempo reakcji), a jego strukturę stanowi 6 podstawowych cech, tj. Żwawość, perseweratywność, aktywność, reaktywność emocjonalna, wrażliwość sensoryczna i wytrzymałość. Każda z sześciu cech jest mierzona za pomocą kwestionariusza FCZ-KT. Test jest dość obszerny, składa się bowiem ze 120 twierdzeń, zatem każda cecha badana jest 20 razy, za pomocą 20 różnych pozycji testowych. Do każdego twierdzenia badany musi się ustosunkować, zaznaczając odpowiedź „tak” lub „nie”.

Jak podkreślają badacze z nurtu językoznawstwa kognitywnego, każdy komunikat językowy wywołuje u odbiorcy określoną konceptualizację, która bazuje na jego własnych doświadczeniach, światopoglądzie, przechowywanych w umyśle schematach i scenariuszach. Bardziej uszczegółowiony (oparty na hiponimach) komunikat zawęża możliwe interpretacje, zaś komunikat schematyczny (oparty na hiperonimach) otwiera szersze pole do skonceptualizowania treści wedle jednostkowego, subiektywnego klucza zasobów poznawczych użytkownika języka (Taylor 2007: 146).

Jedną z kwestii istotnych z punktu widzenia językoznawstwa, którą muszą rozstrzygnąć autorzy testów psychologicznych, jest właśnie stopień uogólnienia pozycji testowych. Zbytnie uszczegółowienie może spowodować to, że test będzie dyskryminujący dla określonej części populacji lub że badani nie będą w stanie utożsamić się z danym twierdzeniem, jeśli dotyczy ono sytuacji lub zdarzeń, które wykraczają poza ich doświadczenie. Dlatego autorzy częściej decydują się na sformułowanie pozycji testowych na dość wysokim poziomie schematyczności, aby każdy badany mógł dopasować go do indywidualnej sytuacji. Taka właśnie strategia została obrana w przypadku FCZ-KT. Nasuwa się jednak zasadnicze pytanie: 
czy w przypadku wysokiego poziomu schematyczności badani nie będą interpretować twierdzeń w tak różny sposób, że w istocie odpowiadać będą na różne pytania, zaś uzyskane przez nich wyniki będą w istocie odbiegać od założeń teorii, na której zbudowano test. Problem ten jest przedmiotem omówionego w niniejszym artykule badania.

\section{Przebieg badania}

Badanie przebiegało dwuetapowo. Na początku przeprowadzono pilotaż, w którym wzięło udział 30 osób. Respondenci wypełniali kwestionariusz FCZ-KT i oceniali stopień trudności (w skali od 1 do 3) każdej pozycji testowej. Wyniki poddano analizie statystycznej i za pomocą miar tendencji centralnej wyodrębniono 20 pozycji, które badani ocenili jako niejasne i które przysparzały im najwięcej problemów interpretacyjnych.

Następnie przeprowadzono badanie właściwe, w którym wzięło udział 637 osób. Próba została dobrana wedle grup normalizacyjnych ${ }^{4}$ występujących w teście FCZ-KT. Zadaniem respondentów było ustosunkowywanie się do 20 pozycji testowych wyodrębnionych w pierwszym etapie badania. Co istotne, każdy badany był proszony o zanotowanie, co sobie wyobraził, o czym myślał podczas udzielania odpowiedzi na każde z tych pytań. Odpowiedzi opisowe (wyobrażenia badanych wywołane treścią poszczególnych pozycji testowych) podzielono na poszczególne kategorie.

\section{Wyniki badania}

Analizie poddano problematyczne pytania odzwierciedlające wszystkie sześć cech mierzonych testem FCZ-KT, jednak ze względu na obszerność samego materiału i uzyskanych wyników w niniejszym tekście przedstawiono szczegółowe opracowanie dwóch pozycji testowych diagnostycznych dla dwóch cech - wytrzymałości i wrażliwości sensorycznej, pozostałe zaś zostaną omówione w kolejnych publikacjach.

Przedstawione poniżej kategorie i podkategorie wyodrębniono na podstawie analizy odpowiedzi wszystkich badanych. Przytoczone dla każdej kategorii przykłady konceptualizacji cytowano dosłownie, aby unaocznić, w jaki sposób respondenci rozumieją dane stwierdzenie i

${ }^{4}$ Każdy znormalizowany test umożliwia interpretację wyników w odniesieniu do różnych podgrup badanej populacji, podzielonej przede wszystkim ze względu na płeć i wiek. W teście FCZ-KT istnieją odrębne normy oceny wyników dla kobiet i dla mężczyzna w następujących przedziałach wiekowych: 15-19 lat, 20-29 lat, 30-39 lat, 40-49 lat, 50-59 lat, 60-80 lat. 
aby móc odnieść przytoczone subiektywne interpretacje badanych do założeń teoretycznych autorów.

\subsection{Wytrzymałość}

W myśl Regulacyjnej Teorii Temperamentu wytrzymałość to zdolność właściwego reagowania na długotrwałe lub silnie stymulujące bodźce. Osoba o niskiej wytrzymałości źle znosi obciążenie psychiczne, stres i zagrożenie, a długotrwała praca czy nagłe trudne sytuacje życiowe są dla niej wyczerpujące (Zawadzki, Strelau 1997: 149).

Pozycją testową zakwalifikowaną do analizy w ramach omawianego badania w kategorii wytrzymałość jest pozycja 18: Potrafię się odprężyć w hałaśliwym pomieszczeniu. Potoczna i słownikowa definicja leksemu „odprężyć się” odsyła do osiągania stanu relaksu, komfortu psychicznego, uspokojenia i odstresowania. Słownikowo hałas to bardzo głośny dźwięk zakłócający spokój (Wielki słownik języka polskiego PAN), z kolei według Międzynarodowej Organizacji Pracy hałas to każdy dźwięk, który może doprowadzić do utraty stuchu, albo być szkodliwy dla zdrowia lub niebezpieczny $z$ innych względów (Konwencja 148 Międzynarodowej Organizacji Pracy 1978, art. 3 pkt b).

Aby badany mógł odnieść się do tej pozycji testowej, musi uszczegółowić przynajmniej jedną z następujących kwestii:

1. Co znaczy „odprężyć się”?

2. Czym jest „hałaśliwe pomieszczenie”?

3. Co jest źródłem hałasu?

W dalszej części przedstawiono kategorie wyodrębnione z odpowiedzi opisowych badanych w odniesieniu do pozycji testowej: Potrafię się odprężyć $w$ hałaśliwym pomieszczeniu. Interpretacje badanych porównano z założeniami teoretycznymi autorów testu.

\subsubsection{Kategoria 1}

\section{SPOSÓB ODPRĘŻENIA}

\section{relaks/sen/możliwość wykonywania zadań(pracy)/trudno powiedzieć}

W myśl założeń teoretycznych RTT omawiana pozycja testowa powinna badać, czy dana osoba potrafi osiągnąc stan komfortu pomimo niesprzyjających warunków panujących w pomieszczeniu, w którym przebywa (Zawadzki, Strelau 1997: 149). Cześć badanych istotnie utożsamiła czasownik odprężyć się z relaksem, odpoczynkiem i odstresowaniem, jednak część z nich uszczegółowił to twierdzenie jako możliwość wykonywania pracy czy obowiązków. 
Przykłady odpowiedzi:

- Hałas mnie zniechęca do wykonywania jakiejkolwiek pracy

- Zwykle pracuję przy głośnym radiu;

- Powtórka materiału do nauki w pociągu;

- Kolokwium na studiach, podczas którego 3/4 osób miało włączone telefony;

- Nie umiem się skupić jeżeli ktoś krzyczy;

- Praca tuż koło autostrady.

Niektórzy respondenci skonkretyzowali odprężyć się jako zasnąć:

- Leżę na łóżku i zasypiam pomimo imprezy tuż przy moich drzwiach;

- O tym, że potrafię spać przy włączonym telewizorze;

- Grające radio a ja śpię.

Uszczegółowienia badanych przedstawiały również sposoby spędzania wolnego czasu. I tak przytaczano zajęcia taneczne, czytanie książki, oglądanie telewizji, słuchanie muzyki czy spędzanie czasu ze znajomymi:

- Przebywanie na zajęciach tanecznych/muzycznych;

- Wiercących w ścianę sąsiadów, a ja spokojnie leżę i oglądam ulubiony film;

- Jadąc autobusem ubieram słuchawki i odpływam na chwilę;

- Czytanie książki w pociągu;

- Siedzę pod ścianą z zamkniętymi oczami, nie myśląc o egzaminie, podczas gdy wszyscy naokoło powtarzają materiał;

- Wyobrażam sobie filiżankę dobrej herbaty i zamykam na chwilę oczy;

- Impreza ze znajomymi;

- Odpoczywam na zakupach.

\subsubsection{Kategoria 2}

\section{RODZAJ POMIESZCZENIA}

\section{konkretne pomieszczenie/konkretna sytuacja/trudno powiedzieć}

W tej kategorii odnotowano całe spektrum różnych pomieszczeń czy miejsc, które badani przytaczali jako swoją konkretyzację hałaśliwego pomieszczenia. Z jednej strony były to miejsca z życia codziennego (dom, miejsce pracy, szkoła, uczelnia), z drugiej miejsca, w których badani byli tylko raz lub w których bywają rzadko, co oznacza, że hałas - w

\footnotetext{
${ }^{5}$ Wszystkie odpowiedzi badanych przytoczono dosłownie.
} 
wyobrażeniach badanych - może występować często lub sporadycznie. Przykładowe odpowiedzi:

- Zasypianie w samochodzie;

- Stadion;

- Super-market;

- Siedzę na dworcu PKP z książką w ręku;

- Odpręża mnie jazda w komunikacji miejskiej;

- W zakładzie krawieckim czytałam książkę;

- W domu wczasowym moje okno w pokoju wychodziło na ruchliwą ulicę. Mimo to czułam się odprężona i zadowolona.

W odpowiedziach podawano również miejsca, które można by skategoryzować jako nietypowe, jako że z zasady nie są one przeznaczone do odprężania się i poszukiwania spokoju:

- Wyobrażam sobie duży urząd z wielką kolejką przy każdym stanowisku;

- Hala produkcyjna, mnóstwo głośnych dźwięków - brak mojej możliwości odprężania;

- Stoję w korku i myślę o życiu.

\subsubsection{Kategoria 3}

\section{PRZYCZYNA HALASU}

czynnik ludzki/czynnik pozaludzki/trudno powiedzieć

dotyczący codziennych sytuacji/dotyczący bardziej sporadycznych sytuacji/trudno określić

$\mathrm{Z}$ odpowiedzi badanych wyłaniają się również odmienne przyczyny hałasu. Dla jednych hałasem są ludzie, dla innych urządzenia. Przykładowe odpowiedzi:

- Remont w pomieszczeniu obok;

- Słucham głośnej muzyki;

- Glośno nastawiony TV w domu;

- Siedzę w fotelu a wokół mnie rodzina której członkowie głośno rozmawiają;

- Pomieszczenie pełne dzieci;

- Na dworze pracuje kosiarka;

- Pompę wody wydobywającą wodę na powierzchnię. Jestem elektrykiem na kopalni;

- Centra handlowe, hale sportowe, środki komunikacji miejskiej. 


\subsubsection{Kategoria 4}

\section{INTENSYWNOŚĆ HALASU}

intensywny dźwięk/dźwięk o umiarkowanym natężeniu/trudno powiedzieć

W odpowiedziach badanych przywoływany jest dźwięk o różnych natężeniach. Przytaczano hałas w zakładzie pracy, w których używany jest ciężki sprzęt, środki komunikacji publicznej, szum uliczny czy rozmowy innych osób. Przykładowe odpowiedzi:

- Wyobrażam sobie zakład pracy z włączonymi głośnymi maszynami obrabiającymi (skrawarkami do metalu, giętarkami, szlifierkami itp.);

- Ciągły szum wentylatorów w ostatniej pracy;

- Nie jestem w stanie odpoczywać gdy za oknem hałasują samochody, zwłaszcza latem gdy okno jest cały czas otwarte;

- Sytuacja w której odwiedziła mnie moja rodzina;

- Grając na telefonie;

- Droga w pociągu do domu;

- Odpoczynek przy włączonej maszynie.

\subsubsection{Kategoria 5}

\section{EKSPOZYCJA NA HALAS}

\section{intencjonalna/nieintencjonalna/trudno powiedzieć}

Jak wynika z analizowanych odpowiedzi, niejednoznaczne jest również to, czy badany ma wpływ na hałas. Z jednej strony respondenci przywoływali miejsce pracy lub nauki, w którym hałas jest poza ich kontrolą, lub prace remontowane prowadzone w mieszkaniu sąsiada, na co oczywiście ma się ograniczony wpływ. Z drugiej strony badani podawali również miejsca, do których udają się z własnej woli, w wolnym czasie. Często jako przykład hałasu podawano głośną muzykę, którą intencjonalnie nastawia i reguluje sam badany.

- O pomieszczeniu, w którym bez przerwy dzwonią telefony;

- Remont sąsiada;

- Potrafię zasnąć na głośnej imprezie;

- Drink w klubie po pracy;

- Czytam książkę przy włączonej muzyce;

- Jestem na plaży pełnej ludzi nie mam szans na odprężenie, nie lubię tego;

- Zajęcia lekcyjne w szkole; 
- Wyobraziłem sobie pomieszczenie, w którym aktualnie przebywam (radio + współpracownik) i próbę odprężenia;

\section{- Koncert.}

\subsubsection{Podsumowanie}

W pierwszej kolejności należy odnotować, że badani różnie interpretowali kwestię ich ewentualnego wpływu na hałas, w którym przebywają. Niedopowiedzeniem w omawianym twierdzeniu jest to, czy przebywanie w hałaśliwym pomieszczeniu jest badanemu narzucone czy też sam decyduje się spędzić czas w hałasie. Można przyjąć, że czym innym jest wyjście do klubu, gdzie słucha się ulubionej muzyki w towarzystwie znajomych, a czym innym próba odprężenia się w miejscu pracy lub nauki (szkoła, uczelnia, zakład pracy). Jako że w wielu odpowiedziach jako przykład hałasu podano głośne słuchanie muzyki, należałoby się zastanowić, czy odtwarzanie ulubionych utworów (niezależnie od intensywności, którą sami ustawimy) można w ogóle sklasyfikować jako hałas. W myśl teoretycznych założeń przyjętych dla cechy wytrzymałośćc, hałas ma stanowić niekorzystne warunki otoczenia i być czymś niepożądanym (co pokrywa się $\mathrm{z}$ definicją hałasu przyjęta w Konwencji PWN i Wielkim słowniku języka polskiego PAN), trudno zatem, aby ulubiona muzyka, którą badany nastawia z własnej woli i dla własnej przyjemności, była czymś niepożądanym i uciążliwym. Być może w rozumieniu części badanych głośna muzyka jest właśnie hałasem, niemniej to wskazywałoby, że potoczne rozumienie różni się od specjalistycznej definicji, a tym samym, że omawiana pozycja testowa nie została sformułowana dość precyzyjnie, co pociąga za sobą różne rozumienia pojęcia hałas.

Jeśli w swojej konkretyzacji badany przywoła średnio intensywny dźwięk lub dźwięki, które sam wybiera i które sprawiają mu przyjemność (koncert, dyskoteka, telewizor, stadion), nadal nie wiemy, jak radzi sobie z intensywniejszymi czy niechcianymi bodźcami, które są związane z cechą wytrzymałości. Niewątpliwie inna jest intensywność hałasu wytwarzanego przez ciężki sprzęt górniczy, lekki sprzęt codziennego użytku (np. wentylatory) a jeszcze inny hałas wytwarzają ludzie, dlatego trudno postawić znak równości między konkretyzacjami badanych w tym aspekcie, co za tym idzie - odpowiedź badanego w tej pozycji testowej może zależeć od przywołanej przez niego konkretyzacji pojęcia hałasu.

Warto też podkreślić, że pojęcie odprężyć się zostało przez część badanych zrozumiane jako skoncentrować się, zatem ich odpowiedzi nie do końca zgadzają się ze znaczeniem 
omawianego twierdzenia i - jak można przypuszczać - założeniami autorów testu, tym samym uzyskane odpowiedzi nie są diagnostyczne.

Na niedookreśloność pytania, a tym samym wynikające $\mathrm{z}$ tego problemy interpretacyjne, zwracali uwagę niektórzy badani, udzielając m.in. takich odpowiedzi:

- To zależy jaki to jest hałas.

- Nie wiem, jak można odprężyć się w hałaśliwym pomieszczeniu nie wiem czym się kierowal autor tego pytania.

- Zależy jaki hałas, ale $\mathbf{z}$ reguły mi to nie przeszkadza.

Reasumując, w uszczegółowieniach respondentów można wskazać następujące różnice:

1) Różnice w sposobie odprężania się:

- odprężenie rozumiane jako umiejętność skupienia się na zadaniu/pracy,

- odprężenie jako określona aktywność - taniec, udział w koncercie, zakupy,

- odprężenie jako brak aktywności - trwanie w bezruchu,

- odprężenie jako sen.

2) Różnice $\mathrm{w}$ częstotliwości przebywania w hałaśliwym pomieszczeniu:

- miejsca odwiedzane codziennie - miejsce pracy, nauki, dom,

- miejsca odwiedzane często - kawiarnia, środek komunikacji,

- miejsca odwiedzane rzadko - stadion, miejsce koncertu, urząd.

3) Różnice w możliwości wyboru hałaśliwego pomieszczenia:

- miejsca, w których badany musi przebywać - praca, szkoła, komunikacja miejska,

- miejsca, w których badany chce przebywać - koncert, stadion, kawiarnia, klub.

4) Różnice w zakresie intensywności hałasu:

- dźwięk o normalnym natężeniu, wytwarzany przez przedmioty/sprzęty codziennego użytku - telefon, autobus, samochód,

- dźwięk o nadmiernym natężeniu, wytwarzany przez ciężki sprzęt, głośno pracujące maszyny - kosiarka, młot pneumatyczny, maszyny górnicze.

5) Różnice ze względu na przyczyny (źródło hałasu):

- hałas, którego źródłem są ludzie,

- hałas, którego źródłem są maszyny i urządzenia.

6) Różnice w zakresie wpływu na hałas:

- hałas, którego źródłem nie jest działanie badanego i na który nie ma on wpływu (szum w pracy, remont sąsiada), 
- hałas, którego źródłem nie jest działanie badanego, na który ma on wpływ (impreza, koncert),

- hałas, którego źródłem jest działanie badanego (puszczona głośno muzyka, telewizor).

Mając na uwadze powyższe, zasadnicze pytanie brzmi, czy tak duża swoboda wyobrażeń w ogóle pozwala na wnioskowanie o cesze wytrzymałość, jeśli badani przywołują zupełnie różną intensywność, rodzaj czy źródło hałasu, różnie też rozumieją pojęcie odprężyć się? Bycie nieodpornym na dźwięk maszyn górniczych nie świadczy o niskiej wytrzymałości, gdyż być może to rodzaj hałasu, którego po prostu nie sposób tolerować. Z kolei możliwość czytania książki w pociągu niekoniecznie świadczy o dużej wytrzymałości i nie może być opozycją dla odpowiedzi, w której badanych wyobraża sobie ciężki sprzęt górniczy. Zakład krawiecki, kopalnia, urząd, supermarket, dworzec, wytwarzają zupełnie inne typy hałasu, stąd być może porównywanie odpowiedzi badanych jest w ogóle nieuprawnione. Zastanawiające jest również to, że w niektórych konkretyzacjach podawano miejsce, które z założenia nie jest miejscem przeznaczonym do odprężenia, np. wspomniany urząd: do urzędu idziemy, aby dokonać instrumentalnych czynności, nie zaś po to, by się odprężać. Oznacza to, że wysoki stopień schematyczności sprzyja różnorodnym interpretacjom badanych, tym samym twierdzenie: potrafię się odprężyć $w$ hałaśliwym pomieszczeniu może nasuwać negatywne skojarzenia (irytujące dźwięki w nielubianym pomieszczeniu) lub pozytywne (głośne, ale przyjemne dźwięki w lubianym pomieszczeniu), a uzyskane odpowiedzi mogą odbiegać od przyjętych założeń teoretycznych autorów testu.

\subsection{Wrażliwość sensoryczna}

Cecha ta odnosi się do zdolności spostrzegania nawet słabych, nisko stymulujących bodźców zmysłowych (Zawadzki, Strelau 1997: 148). Osoby o wysokiej wrażliwości sensorycznej intensywnie reagują na słabe bodźce, czego efektem jest duże wyczulenie na otoczenie zewnętrzne. Wysoka wrażliwość sensoryczna wiąże się ze spostrzegawczością i czujnością w sferze poznawczej.

Jedną z pozycji testowych badających wrażliwość sensoryczną jest twierdzenie nr 2, które zostało w pierwszym etapie badania wyodrębnione jako problematyczne: $W$ nocy dostrzegam plynace po niebie chmury.

Słownikowo dostrzec oznacza widzieć coś, co nie jest dobrze widoczne (Wielki słownik języka polskiego PAN). Jak wynika z definicji cechy wrażliwość sensoryczna, dostrzeganie 
musi być powtarzalne i stanowić pewną stałą dyspozycję badanego, dlatego użyto aspektu niedokonanego czasownika dostrzegać. W przypadku tej pozycji testowej dostrzeganie musi mieć miejsce w nocy - to jedyny warunek, który przyjęli autorzy testu. Ponadto sformułowanie płynace po niebie chmury jest zbyt metaforyczne jak na narzędzie diagnostyczno-badawcze.

Konstrukcja pozycji testowej wymaga od badanego uszczegółowienia przynajmniej jednej z następujących kwestii:

1. W jakim miejscu można dostrzegać płynące po niebie chmury?

2. W czasie jakich czynności można dostrzegać płynące po niebie chmury?

3. Co oznacza dostrzec chmury?

4. Czy dostrzeganie jest intencjonalnym działaniem czy też dzieje się samoczynnie?

Na podstawie odpowiedzi osób badanych wyszczególniono 4 kategorie wyobrażeń, jakie badanym przywodzi na myśl analizowana pozycja testowa.

\subsubsection{Kategoria 1}

\section{MIEJSCE DOSTRZEGANIA}

\section{wewnątrz budynku/na zewnątrz/trudno powiedzieć}

W pierwszej kolejności respondent musi dokonać uszczegółowienia miejsca dostrzegania ruchu chmur, którego w żaden sposób nie określają autorzy testu. W odpowiedziach respondenci wskazywali zarówno miejsca wewnątrz jakiegoś budynku - najczęściej domu/mieszkania, jak i miejsca na zewnątrz - łąka, las, droga, chodnik, bliżej nieokreślona otwarta przestrzeń.

- $\quad$ Stoję przy oknie i patrzę na niebo.

- Wyobraziłem sobie sypialnię.

- Nie mam okien dachowych.

- Spanie w namiocie.

- Letnia noc w wakacje.

- Wakacyjne niebo w górach.

- Leżę na lące, patrzę w niebo.

- W czasie spacerów, na które nie mam czasu.

\subsubsection{Kategoria 2}

\section{KONTEKST DOSTRZEGANIA}

aktywność w czasie wolnym/wykonywanie obowiązów/zasypianie/inne/trudno powiedzieć 
Aby dostrzegać ruch chmur, badany musi mieć ku temu możliwość, tym samym musi odpowiedzieć sobie na pytanie: w jakich okolicznościach, w jakich momentach ewentualnie mógłbym spoglądać w niebo i dostrzegać płynące po nim chmury? Często w odpowiedziach przywoływane są wakacje i okres letni, kiedy zwyczajowo ludzie częściej przebywają na zewnątrz. Drugim równie częstym kontekstem jest moment zasypiania.

- Kiedy mam chwilę czasu, żeby pójść na wieczorny spacer i popatrzeć w niebo;

- Powrót samochodem z zebrania;

- Wyobraziłam sobie moment zasypiania oraz leżenie w lóżku przed zaśnięciem;

- W nocy śpię i nie widzę chmur;

- Wyobraziłam sobie siebie w lóżku patrzącą w okno (moje lóżko znajduje się naprzeciwko okna, zawsze patrzę na niebo przed zaśnięciem);

- Koniec grilla i patrzę na niebo;

- Podczas prowadzenia obserwacji astronomicznych, ruch chmur jest ważnym aspektem podczas wykonywania specjalistycznych obliczeń.

\subsubsection{Kategoria 3}

\section{PRZEDMIOT DOSTRZEGANIA}

chmury/wiatr/księżyc/gwiazdy/brak/trudno powiedzieć

$\mathrm{Z}$ treści omawianej pozycji wynika, że przedmiotem dostrzegania powinien być ruch chmur, jednak część badanych w swoich uszczegółowieniach przytacza nie tylko „płynące po niebie chmury”, ale również inne elementy nieboskłonu. W niektórych odpowiedziach - mimo że badany odpowiedział na pozycję testową twierdząco - w ogóle nie jest przywołany ruch chmur ani nawet same chmury. Oznacza to, że w świadomości wielu badanych niebo ma określoną konotację, na którą składają się powiązane ze sobą elementy: księżyc, gwiazdy i chmury lub brak chmur.

- Chmury płynące po niebie, a w tle księżyc, co ułatwia widzenie tego zjawiska.

- Spacer pod rozgwieżdżonym niebem w ciepłą, letnią noc.

- Wyjazd z przyjaciółmi w Bieszczady i obserwowanie spadających gwiazd wśród chmur.

- Niebo ciemne, bez gwiazd i księżyca, patrzę z okna.

- Stoję na podwórku i obserwuję niebo. Świeci księżyc.

- Jasne rozgwieżdżone niebo, pełnia księżyca i płynące niewielkie chmury po niebie. 
- Stoję na balkonie i oglądam Księżyc paląc papierosa. Widzę ogólny obraz, ale bardziej jako zdjęcie niż ruchomą rzeczywistość.

- Niebo jest prawie jednolicie ciemne.

\subsubsection{Kategoria 4}

\section{SPRAWSTWO W DOSTRZEGANIU}

dostrzeganie samoczynne/dostrzeganie intencjonalne/trudno powiedzieć

Zasadniczą kwestią, którą musi rozstrzygnąć badany, jest to, czy dostrzeganie ruchu chmur przebiega samoczynnie czy raczej zależy od jego intencjonalnego działania, choć w myśl definicji pojęcia wrażliwość sensoryczna test powinien sprawdzać, czy badany sam z siebie dostrzega (jeśli jest ku temu możliwość) słabe bodźce, np. chmury płynące po niebie. Przeanalizowane odpowiedzi pokazały, że respondenci krańcowo różnie rozumieli swój udział w obserwacji nieba: dla jednych obserwacja chmur może przebiegać samoczynnie podczas wykonywania innej czynności (odpoczynku, przemieszczania się, palenia papierosa), w interpretacji innych dostrzeganie ruchu chmur jest możliwe wyłącznie wtedy, gdy jest intencjonalne (spoglądanie, obserwowanie nieba). Co ciekawe, wielu badanych łączyło odpowiedź na to twierdzenie z problemami z bezsennością lub ich brakiem, zatem dla części z nich obserwować chmury można tylko podczas bezsennych nocy lub pod warunkiem, że łóżko znajduje się blisko okna.

- Nie śpię przy oknie.

- Nie, ponieważ jestem w domu, a idąc na trening nordic walking skupiam się na drodze.

- Nie spaceruję w nocy, więc może być to jedynie sytuacja kiedy wracam do domu (np. z imprezy), a wtedy skupiam się na tym, aby jak najszybciej dotrzeć do domu. $\mathrm{Z}$ kolei w domu mam rolety, więc zaobserwowanie takiego zjawiska jest po prostu technicznie niemożliwe.

- Lubię stać w ciemności przy oknie i patrzeć na chmury.

- Idąc w nocy ulicą patrzę pod nogi a nie na niebo.

- W nocy śpię i nie widzę chmur.

- Nie, bo z reguły dobrze sypiam.

- Wyobraziłam sobie, że nie mogę zasnąć i siadam przy oknie, obserwując niebo.

- Wyobraziłam sobie dokładne wpatrywanie się w ciemne niebo, aby móc dostrzec ruch chmur. 


\subsubsection{Podsumowanie}

Jako niezwykle interesujący warto odnotować fakt, iż niektórzy badani utożsamiali płynące po niebie chmury z marzeniem sennym:

- Ciemność, ponieważ przeważnie nie pamiętam snów.

- Śnię o chmurach?

- Rzadko coś mi się śni.

- Nie nigdy nie dostrzegam chmur we śnie.

- Jak śniło mi się sen.

- Wyobraziłam sobie sen.

Być może przyczyną takiego skojarzenia jest fakt, że twierdzenie dotyczące ruchu chmur w nocy jest na tyle enigmatyczne, że asocjowało badanym $\mathrm{z}$ treścią snu, a nie $\mathrm{z}$ tym, czego doświadczają na jawie. Innym wyjaśnieniem powyższych odpowiedzi może być fakt, że noc ma tak silne konotacje ze spaniem, że u niektórych badanych dominuje nad wszelkimi innymi wyobrażeniami, a tym samym nie potrafią właściwie zinterpretować twierdzenia.

Jak pokazują przytoczone odpowiedzi, kontekst i miejsce dostrzegania mogą być kluczowe dla reakcji badanego, bowiem w zależności od tego, jakie okoliczności przywoła, taka będzie jego odpowiedź. Jeśli dla badanego prototypową sytuacją dogodną dla dostrzegania ruchu chmur jest spacer, a niezwykle rzadko ma on okazję wybrać się na wieczorną przechadzkę, odpowiedź będzie negatywna, co jednak niekoniecznie będzie związane z poziomem jego wrażliwości sensorycznej, którą powinno badać omawiane twierdzenie. Uszczegółowienie kontekstu i miejsca jest ściśle powiązana ze sprawstwem w dostrzeganiu. Jeśli w umyśle badanego zostanie przywołany moment przed zaśnięciem i łóżko w sypialni, z którego może obserwować niebo nocą, odpowiedź będzie twierdząca. Z kolei przywołanie w świadomości wieczornych powrotów do domu może skutkować odpowiedzią przeczącą, jeśli badany - w trosce o swoje bezpieczeństwo - porusza się szybko i koncentruje się na unikaniu przeszkód i niebezpieczeństw.

Wyniki pokazują, że badani skrajnie różnie uszczegóławiają omawiane twierdzenie, co budzi wątpliwości, czy reakcja badanego na tę pozycję testową zależy od jego wrażliwości sensorycznej czy raczej od interpretacji twierdzenia oraz dokonanej konkretyzacji poszczególnych elementów sytuacyjnych: oświetlenia lub jego braku, umiejscowienia okna w sypialni, możliwości przebywania i spędzania czasu na zewnątrz (np. czasu, który mogą poświęcić na spacer). Znamienne jest, że w odpowiedziach badanych często pojawiał się warunek, który musi być spełniony, aby byli oni w stanie dostrzec ruch chmur, co niejako stoi 
w sprzeczności z definicją, w myśl której wrażliwość sensoryczna ma być stałą (a nie warunkową) dyspozycją do odbierania bodźców o słabym natężeniu.

Reasumując, w uszczegółowieniach respondentów można wskazać następujące różnice:

1) Różnice w miejscu dostrzegania, a co za tym idzie możliwości dostrzegania:

- pomieszczenia domowe $\mathrm{z}$ dostępem do okna,

- pomieszczenia domowe bez dostępu do okna,

- miejsca poza domem z możliwością obserwowania nieba,

- miejsca poza domem bez możliwości obserwowania nieba.

2) Różnice w kontekście dostrzegania ze względu na możliwość obserwowania chmur:

- czynności umożliwiające obserwację nieba,

- czynności, podczas których nie jest możliwe obserwowanie nieba.

3) Różnice w częstotliwości wykonywania czynności, która sprzyja obserwowaniu chmur:

- czynności wykonywane często/codziennie (podróż z pracy, zasypianie),

- czynności wykonywane od czasu do czasu (spacer, spotkanie ze znajomymi),

- czynności wykonywane rzadko/okazjonalnie (wyjazd wakacyjny do konkretnego miejsca).

4) Różnice w przedmiocie dostrzegania:

- dostrzeganie chmur i innych zjawisk (księżyca, wiatru, gwiazd),

- dostrzeganie innych zjawisk bez dostrzegania ruchu chmur,

- dostrzeganie ruchu chmur,

- dostrzeganie nieba jako statycznego obrazu.

5) Różnice w zaangażowaniu obserwatora w dostrzeganie:

- czynności intencjonalne, których celem jest dostrzeżenie ruchu chmur (wpatrywanie się w niebo, celowe spoglądanie przez okno),

- mimowolne dostrzeganie ruchu chmur podczas wykonywania jakiejś czynności.

\section{Dyskusja}

Test psychologiczny bazujący na materiale werbalnym jako narzędzie diagnostyczne i badawcze, konstruowane w oparciu o przyjętą przez autorów teorię psychologiczną lub model psychologiczny, stanowi zbiór zadań (pozycji), które mają umożliwić pobranie pewnej próbki zachowań tak, aby na jej podstawie można wnioskować o zachowaniu badanego w sytuacjach pozatekstowych. Aby test oparty na pytaniach i twierdzeniach słownych mógł być rzeczywistą 
próbką zachowania, autorzy muszą mieć świadomość tego, że każdy tekst jest osadzony w dotychczasowym doświadczeniu badanego, wywołuje w nim określone skojarzenia i podlega jego subiektywnej interpretacji, język bowiem stanowi odzwierciedlenie całego doświadczenia człowieka, poznawanych faktów, doznań płynących z kontaktu z rzeczywistością. Jest również środkiem poznania, zdobywania wiedzy i kształtowania się ludzkiego doświadczenia. Każde obcowanie $\mathrm{z}$ tekstem i językiem jest składową doświadczenia, i odwrotnie - każde doświadczenie ma swoje odzwierciedlenie w języku (Tabakowska 2001: 29).

Zadaniem twórców testów psychologicznych jest przywołanie w umyśle osoby badanej pożądanych skojarzeń, zgodnych $\mathrm{z}$ założeniami teoretycznymi leżącymi u podstaw konstruowanych narzędzi, przy jednoczesnym pozostawieniu pola na umiejscowienie ich w jednostkowym doświadczeniu. Autorzy testów muszą mieć również świadomość tego, że sami obarczeni są bagażem subiektywnych znaczeń, indywidualnych prototypów czy egzemplarzy, dlatego bez odpowiednich analiz badawczych nie mogą przewidzieć, czy odbiorca testu (badany) zrozumie go i zinterpretuje w zamierzony przez nich sposób.

Jak pokazuje przedstawione wyżej badanie, wybór pozycji testowych o wysokim poziomie schematyczności pozostawia badanym zbyt duże pole do subiektywnej interpretacji tym samym poszczególne uszczegółowienia znacznie różnią się między sobą, ale też istotnie oddalają od przyjętych ram teoretycznych. Wydaje się, że dla testów słownych dobrym i słusznym rozwiązaniem byłoby badanie prototypów cech, zachowań, reakcji czy problemów, które ma diagnozować test, a które należałoby sprawdzać dla każdej populacji osobno. Rozwój badań interdyscyplinarnych, a co za tym idzie włączanie do etapu konstrukcji testów psychologicznych konsultacji językoznawczych $\mathrm{z}$ pewnością przyczyniłoby się do podniesienia jakości narzędzi badawczych stosowanych w psychologii.

W 2016 roku test FCZ-KT został poddany rewizji, czego efektem jest opracowanie jego nowej wersji FCZ-KT(R). Jak wskazują autorzy wersji zrewidowanej, główną motywacją do prac nad nowym narzędziem były wady psychometryczne kwestionariusza oraz brak zbilansowania treściowego. Ponadto zwrócono uwagę na konieczność rewizji treści pozycji testowych po upływie ok. 20 lat ze względu na zmiany kulturowe, które dokonały się w społeczeństwie, a których odzwierciedleniem jest język (Cyniak-Cieciura, Zawadzki, Strelau 2016: 4-6). Nie wiadomo, czy badacze zaprosili specjalistów z innych dziedzin do współpracy przy konstrukcji nowego narzędzia. Dwie szczegółowo analizowane w niniejszym artykule pozycje testowe, które na podstawie badań zostały uznane za problematyczne, zostały usunięte z nowej wersji kwestionariusza. Fakt ten potwierdza pośrednio poprawność przyjętej przez 
autorki metodologii oraz daje nadzieję, że psycholodzy konstruujący testy będą w przyszłości zwracać większą uwagę na warstwę językową kwestionariuszy.

\section{Bibliografia}

American Educational Research Association i in. (2007) Standardy dla testów stosowanych w psychologii i pedagogice. Gdańsk: Gdańskie Wydawnictwo Psychologiczne.

Brzeziński, Jerzy (2003) Metodologia badań psychologicznych. Warszawa: Wydawnictwo Naukowe PWN.

Cyniak-Cieciura, Maria, Bogdan Zawadzki, Jan Strelau (2016) Formalna Charakterystyka Zachowania - Kwestionariusz Temperamentu: Wersja Zrewidowana. Podręcznik. Warszawa: Pracownia Testów Psychologicznych Polskiego Towarzystwa Psychologicznego.

Guilford, Joy P. (2005) „Tworzenie testu”. [W:] Jerzy Brzeziński (red.) Trafność i rzetelność testów psychologicznych: wybór tekstów. Gdańsk: Gdańskie Wydawnictwo Psychologiczne; 107-166.

Hornowska, Elżbieta (2007) Testy psychologiczne: teoria i praktyka. Warszawa: Scholar. Konwencja Nr 148 Międzynarodowej Organizacji Pracy dotycząca ochrony pracowników przed zagrożeniami zawodowymi $w$ miejscach pracy, spowodowanymi zanieczyszczeniem powietrza, hałasem i wibracja. Dz.U. 2005 nr 66 poz. 574.

Mańkowska, Maria (2010) Wprowadzenie do psychometrii. Lublin: Wydawnictwo KUL. Tabakowska, Elżbieta (2001) Językoznawstwo kognitywne a poetyka przekładu. Kraków: Universitas.

Taylor, John R. (2007) Gramatyka kognitywna. Kraków: Universitas.

Wielki słownik języka polskiego (2007) Piotr Żmigrodzki (red.). PAN. [pobrane z: http://www.wsjp.pl/index.php?pokaz=wstep\&l=5\&ind=0?pwh=0. Data ostatniego dostępu: 16.04.2018].

Zawadzki, Bogdan, Jan Strelau (1995) Formalna Charakterystyka Zachowania Kwestionariusz Temperamentu. Warszawa: Pracownia Testów Psychologicznych Polskiego Towarzystwa Psychologicznego.

Zawadzki, Bogdan, Jan Strelau (1997) Formalna charakterystyka zachowania-kwestionariusz temperamentu (FCZ-KT): Podręcznik. Warszawa: Pracownia Testów Psychologicznych Polskiego Towarzystwa Psychologicznego. 